\title{
Servet Vergilerinden Veraset ve İntikal Vergisi Üzerine Değerlendirmeler
}

\author{
The Evaluations of Inheritance and Gift Tax As Property Taxes
}

\author{
Havva ŞAFAK ${ }^{1}$, Hatice YURTSEVER ${ }^{2}$
}

\begin{abstract}
ÖZET
Veraset ve intikal vergisi, servet vergileri içinde yer alan ve servet transferi üzerinden alınan bir vergidir. Ülkemizde, toplam vergi gelirleri içinde çok düşük bir paya sahip olan veraset ve intikal vergisi, toplumsal işleve sahip bir vergidir. Bu özelliğ nedeniyle, verginin mali işlevi daha geri planda kalmaktadır. Veraset ve intikal vergisi, ülkemizde ilk defa 1926 yılında 797 sayılı Kanun ile uygulanmış, 1959 yılında 7338 sayılı Kanun ile değişiklikler yapılmasına rağmen, esaslı bir değişiklik söz konusu olmamıştır. Mali güç ilkesi gereğince veraset ve intikal vergisi, alınması gerekli bir vergidir. Çünkü mali gücün göstergeleri arasında gelir ve harcamanın yanında servet de yer almaktadır. Bu ilkenin varlığı, Anayasa' nın 2. maddesinde yer alan "sosyal devlet" kavramının yanı sıra, 73. maddede yer alan "ödeme gücüne göre vergilendirme" tabirinde de kendini göstermektedir.
\end{abstract}

Anahtar Kelimeler: Türk vergi sistemi, dolaysız vergiler, servet vergileri, veraset ve intikal vergisi.

\section{GíRiş}

Anayasa' nın 73. maddesinde ortaya çıkan "mali güç" kavramı, bireylerin sahip oldukları gelir, servet ve bu varlıklarla tükettikleri yani harcadıkları değerleri ifade etmektedir. Mali güç ilkesine göre ülkemizde, gelir üzerinden, gelir ve kurumlar vergisi; harcamalar üzerinden, özel tüketim vergisi, katma değer vergisi vb.; servet üzerinden ise emlak vergisi, motorlu taşıtlar vergisi ve veraset ve intikal vergisi alınmaktadır.

Servet üzerinden alınan vergileri, direkt servetten ve servetin transferinden alınan vergiler olarak ikiye ayırabilmek mümkündür. Ülkemiz açısından bakıldığında, servetten alınan vergiler olarak emlak ve motorlu taşıtlar vergisini; servet transferinden alınan vergiler olarak ise veraset ve intikal vergisini görmek mümkündür.

Veraset ve intikal vergisi, periyodik olarak alınan bir vergi olmayıp, verginin konusu itibariyle, ölüm olayının veya karşııısız intikallerin gerçekleşmesi sonucu arızi olarak alınan bir vergidir. Hiç şüphesiz, toplumlardaki gelir dağılımı adaletinin sağlanması, vergi yükünün adil bir şekilde dağılımı gibi amaçları

\begin{abstract}
Inheritance and gift tax is a kind of property tax and collected through transfer of assests. Inheritance and transfer tax has a social function taking a low ration in the total tax reveneus in Turkey. Due to this feature of it, fiscal function of tax is left in the background. Inheritance and transfer tax was implemented for the first time in 1926 with the law no797 in Turkey and in 1959 very fundamental changes were made by law no.7338. Despite various alterations until today, no radical change a, has been made. According to the principle of ability to pay, Inheritance and transfer tax is a must to be collected. It is because possessions and income also take place among indications of the ability to pay. The existance of this principle also aperas in the concept of 'social state' in the 2nd article and the term of 'taxation according to the ability to pay'in the 73rd article of the constitution.
\end{abstract}

Keywords: Turkish tax system, direct taxes, property taxes, Inheritance and gift tax.

sağlama yönünden veraset ve intikal vergisinin yeri oldukça önemlidir.

\section{LITERATÜR ÖZETi}

Modern vergi sistemlerinde servet dağılımını düzeltmenin bir aracı olarak önemli bir fonksiyonu olan veraset ve intikal vergileri, veraset yolu ile veya diğer herhangi bir şekilde karşılıksız olarak elde edilen servet unsurlarını vergilendiren ve hemen her ülkede aynı kanunla düzenlenmesine rağmen, prensip olarak, iki ayrı vergiden oluşan bir servet vergisi tipidir (Turhan, 1998:184). Winston Churchill (1874 - 1965) veraset vergisini, yaşayanlardan ziyade ölen kişilerin vergilendirilmesi olarak adlandırmaktadır(Gale, 2001:1). İntikal vergisi, veraset vergisi uygulanan ölüm intikalleri gibi, yaşam boyu varlıkların intikallerine uygulanır (Joulfaian, 1998:4).

Servet vergilerinin en tipik örneklerinden birisi olan veraset ve intikal vergisi, uygulamada ilk ortaya çıkan servet vergilerinden birisi olduğu gibi, uygulandığı ülkeler itibariyle de en geniş uygulama alanına sahip bir servet vergisidir (Çelik, 1995:101). Veraset vergisi, gelecek nesillere miras bırakma ve şimdi tü-

' Mali Hukuk Uzmanı, Celal Bayar Üniversitesi, Sosyal Bilimler Enstitüsü, email: havva.safak@hotmail.com

${ }^{2}$ Doç. Dr., Celal Bayar Üniversitesi, Salihli Meslek yüksekokulu, Dış Ticaret Bölümü, yurtseverhatice@gmail.com 
ketme seçenekleri arasındaki seçimin teşvik ediciliğini etkilemektedir (Cremer, Pestieau, 2003:2).

$\mathrm{Bu}$ vergiler, yaşayanlar arasında servetin aktarılması olarak intikal vergisi, servet sahibinin ölümü üzerine servet vergisi olarak olayların kesin ortaya çıkmasında, düzensiz aralıklarda toplanan vergilerdir (Rosen 2001:459). Ancak varis veya kendisine bağış yapılan kişi hakkında vergi borcunun doğması için bunların miras veya bağışı reddetmemiş olmaları lazımdır (Aksoy, 1991:392).

Veraset vergisi, tereke vergisi ve miras payları vergisi olarak iki türlü uygulanabilmektedir. Bu iki vergileme biçiminden birincisinde murisin bıraktığı servetin bütünü, mirasçıların payları dikkate alınmaksızın vergilenmekte, ikincisinde ise vergi terekenin bütününden değil, miras paylarından alınmaktadır (Uluatam, 2011:365). Bunlardan kuramsal olarak terekenin ya da miras paylarının vergilendirilmesi usulü içerisinde gerçekleştirilebildiği gibi, bunların karma uygulamasına da yer verilebilmektedir (Akdoğan, 2003:371).

\section{TÜRKIYE' DE VERASET VE INTIKAL VERGISINE ILIŞKIN MEVZUAT VE UYGULAMADA KARŞILAŞILAN SORUNLAR}

Ülkemizde veraset ve intikal vergisi, 1926 yılından itibaren uygulanmakta olan bir servet vergisi türüdür. Konulduğu günden bugüne çeşitli değişikliklere uğramıştır.

Veraset ve intikal vergisi kanunu (ViVK), 23 maddeden oluşmaktadır. Veraset ve intikal vergisinde, miras paylarının vergilendirilmesi usulü belirlenmiştir. Böylece mirasın tamamı değil, her bir mirasçının payına düşen miktar vergilendirilmektedir (Kalenderoğlu, 2006). Veraset ve intikal vergisi hasılatı, 2012 yılında 307.985.192 TL olup, bu verginin toplam bütçe gelirleri içindeki payı ise, \% 0.1' dir (TC. Maliye Bakanlığı, 2012:89)

\subsection{Konusu}

Veraset ve intikal vergisinin konusunu veraset yoluyla (vasiyet, miras) veya ivazsız olarak (bağış, piyango, kura, tesadüf oyunu v.b. yollardan) bir kişinin mal varlığından diğer kişinin mal varlığına geçen menkul veya gayrimenkul mallar teşkil etmektedir (Tosuner, Arıkan, 2010:443). Milli piyango ikramiyeleri ise, Milli Piyango Teşkiline Dair Kanuna konulan bir hükümle V.I.V.K. ' nun konusu dışında bırakılmıştır (Bilici, 2010:275). Bunun yanında kumar kazancının da bir ivazsız intikal olduğu ve bunun sonucunda da veraset ve intikal vergisine tabi tutulması gerektiği Danıştay kararı ile belirlenmiştir (Dn.7. K. No: 1999/1502, E. No: 1998/96, 15.04.1996, 15.04.1996 sayılı kararı).
7338 Sayılı V.I.V.K. ' nun 1. maddesinde verginin konusu belirtilmiştir. Buna göre; TC uyruğunda bulunan şahıslara ait mallar ile Türkiye'de bulunan malların veraset yoluyla veya herhangi bir suretle olursa olsun karşılıksız bir tarzda bir şahıstan diğer şahsa intikali veraset ve intikal vergisine tabidir. Bu vergi, Türk uyruğunda bulunan şahısların yabancı memleketlerde aynı yollardan elde edecekleri malları da kapsar.

\subsection{Verginin Mükellefi}

V.I.V.K.'nun 5. maddesinde verginin mükellefi belirtilmiştir. Buna göre; veraset ve intikal vergisinin mükellefi, veraset yoluyla veya ivazsız bir tarzda mal edinen kişidir. Kanunun 2. maddesinde ayrıca kişi kavramına gerçek kişiler ile tüzel kişilerin girdiği açıkça belirtilmiştir. Buna göre, muafiyet kapsamına girmeyen tüzel kişiler de bu verginin yükümlüsü olabilmektedir (Öncel, Kumrulu, Çağan, 2003:379).

Ölüm veya buna bağlı verasetin mevcudiyeti, mirasçının mükellef sayılması için yeterli değildir. Mirasçının mükellefiyeti, üç aylık süre içinde mirası reddetmemesi olayına bağlıdır (Maç, Jamali, 2012:1). İvazsız intikallerde ise, menkul veya gayrimenkul malın intikal edilen kişiye geçmesi mükellefiyet için yeterlidir.

"Miras, üç ay içinde reddolunabilir. Bu süre, yasal mirasçılar için mirasçı olduklarını daha sonra öğrendikleri ispat edilmedikçe miras bırakanın ölümünü öğrendikleri; vasiyetname ile atanmış mirasçılar için miras bırakanın tasarrufunun kendilerine resmen bildirildiği tarihten işlemeye başlar."

Oysa ViVK' na ilişkin mirasçıların yükümlülüklerini yerine getirmeleri için düzenlenen süre, medeni kanun düzenlemesinin aksine, ölümün öğrenildiği tarihi değil ölüm tarihini esas almaktadır. Her iki kanunun aynı konuya ilişkin olarak içerdikleri düzenlemeler sürelerin başlangıcı konusunda bir paralellik göstermemekte, ölüm olayının veraset ve intikal vergisi beyannamesi vermekle yükümlü mirasçılar tarafından ölüm tarihinden çok sonra öğrenilmesi, beyanname vermekle yükümlü mükellefler açısından büyük mağduriyetlere neden olabilmektedir (Öz, 2013:1).

\subsection{Beyannamenin Verileceği Yer}

V.I.V.K.' nun 6. maddesine göre, veraset ve intikal vergisi, Veraset yoluyla olan intikallerde ölen kimsenin, diğer suretle meydana gelen intikallerde tasarrufu yapan şahsın ikametgahının, hükmi (tüzel) şahıslarda ve diğer teşekküllerde merkezlerinin bulunduğu; muris veya tasarrufu yapan şahsın bu ikametgahı yabancı bir memlekette ise Türkiye'deki son ikametgahının bulunduğu; muris veya tasarrufu yapan şahıs Türkiye'de hiç ikamet etmemiş veya son ikametgahı tespit olunamamış ise Maliye Bakanlığının tayin ede- 
ceği yer vergi dairesi tarafından tarh olunur.

\subsection{Beyanname Verme}

V.I.V.K.' nun 7. maddesine göre, veraset yoluyla veya sair suretiyle ivazsız bir tarzda mal iktisap edenler, iktisap ettikleri malları, 5602 sayllı Kanun kapsamında şans oyunları düzenleyen ilgili kurum ve kuruluşlar ile yarışma ve çekilişi düzenleyen gerçek ve tüzel kişiler ikramiye kazananların ikramiyelerinden kesilen vergileri, bir beyanname ile bildirmeye mecburdurlar.

Aynı maddenin devamında, beyanname verme zorunluluğu olmayanlar belirtilmiştir. Türkiye Jokey Klübü Spor Toto Teşkilatının düzenlediği bahislerde ikramiye kazananlar, yarışma ve çekilişlerde ikramiye kazanan nihai tüketiciler, veraset ve intikal vergisinden muaf olanlar, istisna hadleri içinde kalanlar ve ticari plaka sahiplerinin beyanname verme zorunluluğu bulunmamaktadır.

İvazsız intikallere ilişkin olarak 30 seri nolu Genel Tebliğ' de belirleme yapılmış ve ivazsız surette olan intikallerden istisna haddi altında kalanlar için beyanname verilmeyeceği belirtilmiştir. Ancak, veraset yoluyla meydana gelen ve istisna haddi altında kalan intikaller için vergi idaresi tarafından yapılan uygulama şöyledir:

Vergi dairelerine gelen vukuat ve ölüm bildirimleri üzerine mükelleflere beyana çağı mektubu gönderilir. Beyana çağrı mektubuna mükellef tarafından cevaben, kendilerine intikal eden bir mal olmadığının bildirilmesi halinde, beyanname verilmesi istenmemekte ve usulsüzlük cezası da kesilmemektedir.

\subsubsection{Beyanname Verme Süreleri}

Veraset ve intikal vergisinde beyanname verme süresi, veraset yoluyla intikallerde ve ivazsı intikallerde değişiklik göstermektedir. V.I.V.K.' nun 9. maddesinde beyanname verme süreleri belirtilmiştir.

\subsubsection{Veraset Yoluyla İntikallerde Beyanname Verme Süresi}

Veraset yoluyla meydana gelen intikallerde; ölüm Türkiye' de meydana gelmiş ise mükelleflerin Türkiye'de bulunmaları halinde ölüm tarihini takip eden dört ay içinde; mükelleflerin yabancı bir memlekette bulunmaları halinde ölüm tarihini takip eden altı ay içinde; ölüm yabancı bir memlekette meydana gelmiş ise mükelleflerin Türkiye' de bulunmaları halinde ölüm tarihini takip eden altı ay içinde; mükellefler ölü kimsenin bulunduğu memlekette oldukları takdirde ölüm tarihini takip eden dört ay içinde; mükellefler ölü kimsenin bulunduğu yerin dışında başka bir yabancı memlekette oldukları takdirde de ölüm tarihini takip eden sekiz ay içinde; gaiplik halinde, gaiplik kararının ölüm siciline kaydolunduğu tarihi takip eden bir ay içinde beyanname verilir.

Ölüm halinde, mirasçılar dört ay içinde veraset ve intikal vergisi beyannamesi verecekleri için, bu süre dolmadan "sulh hukuk mahkemesi"ne ya da notere başvurup, "veraset ilamı" yani kimlerin ne oranda mirasçı olduklarını gösteren mahkeme kararı almaları gerekmektedir (Kızılot (a), 2013).

\subsubsection{Diğer İvazsız İntikallerde Beyanname Verme Süresi}

Diğer ivazsız intikallerde; gerçek veya tüzel kişilerce düzenlenen yarışma ve çekilişler ile 5602 sayılı Kanunda tanımlanan şans oyunlarında, yarışma ve çekiliş ile müsabakaların yapıldığı günü takip eden ayın yirminci günü akşamına kadar; diğer suretle olan intikallerde malların hukuken iktisap edildiği tarihi takip eden bir ay içinde beyanname verilir.

VUK' nun 342. maddesinde; Veraset ve intikal vergisine ilişkin mükellefiyetlerde tahakkuk muamelesi yapılması için beyanname verme süresinin sonundan başlayarak 15 gün beklenir. Beyanname bu süre içinde verilirse vergi ziyaı olmamış sayılır. Bu süre içinde beyanda bulunan mükellefler için vergi ziyaı söz konusu olmadığı için ikinci derece usulsüzlük kabahati kesilecektir (Akarslan, 2006:4). Ayrıca mükellefe tebliğ edilmek şartı ile yeniden 15 günlük bir mühlet verilir. Bu hususta da yukarıdaki hüküm cari olur, denilmektedir. Bu durumda da mükellefe birinci dereceden usulsüzlük kabahati kesilecektir.

Veraset ve intikal vergisi beyannamesinin, birinci ek süreyi takiben tebliğ yapılarak 342. maddenin ikinci fıkrası uyarınca 15 gün olarak verilen ikinci ek süreden sonra hiç verilmemesi halinde; veraset yoluyla veya ivazsız şekilde mal intikaline ilişkin bilgilere dayanılarak kendisine yazılı tebligat yapılan kişiler adına, intikal ettiği tespit olunan değerler üzerinden tarhı gereken vergi, ihbarname kuralına göre re'sen tarh ve tebliğ edilir. Tarh olunan vergi için kesilmesi gereken iki kat birinci derece usulsüzlük kabahati veya VUK' nun 341 ve 344. maddeleri uyarınca vergi ziyaı kabahati, vergi/ceza ihbarnamesi düzenlenerek muhatabına tebliğ olunur.

Söz konusu 342. madde hükmüyle, sadece veraset ve intikal vergisi mükelleflerine münhasır olmak üzere, normal beyan süresinin bitimini izleyen 15 gün içinde beyanda bulunabilme imkanı tanınmış ve bu süre içerisinde mükelleflerin beyanname vermeleri halinde vergi ziyaının doğmamış kabul edileceği hükme bağlanmış bulunmaktadır (Arıca (c) , 2010:96)

VUK' nun 341. maddesinde, "Vergi ziyaı, mükellefin veya sorumlunun vergilendirme ile ilgili ödevlerini zamanında yerine getirmemesi veya eksik yerine 
getirmesi yüzünden verginin zamanında tahakkuk ettirilmemesini veya eksik tahakkuk ettirilmesini ifade eder" şeklinde tanımı yapılan vergi ziyaı için, söz konusu kanunun 342. maddesinde, vergi dairelerine veraset yoluyla veya ivazsız şekilde mal iktisap edenlerden beyanda bulunmayanlara yazılı tebligat yapılması zorunluluğu getirilmiştir. Buradan da anlaşıldığı üzere, tebligatın yazılı olarak yapılmasının ardından başlayan ikinci 15 günlük sürenin de bitmesi ve halen beyannamenin verilmemiş olması durumunda, vergi ziyaı ortaya çıkmış olmaktadır.

\subsection{Verginin Matrahı ve İlk Tarhiyat}

V.I.V.K.' nun 10. maddesinde verginin matrahı ve ilk tarhiyat ile ilgili açıklamalara yer verilmiştir. Veraset ve intikal vergisinin matrahı, intikal eden malların VUK' na göre bulunan değerleridir. (12. maddede yazııı borç ve masrafların indirilmesi gerektiği takdirde matrah yukarıda yazılı değerlerden bu indirimler yapıldıktan sonra kalan miktardır.)

Mükellefler ilk tarhiyatta dikkate alınmak üzere veraset ve intikal vergisi konusuna giren malları ViVK ve VUK' nun servetleri değerleme ile ilgili 3 . bölümündeki esaslara göre değerlemek ve beyannamelerinde göstermek zorundadırlar.

İdare beyan edilen bu değerler üzerinden vergiyi beyannamenin verildiği tarihten itibaren en geç on beş gün içinde tarh eder. Bu, ilk tarhiyattır. Tarh edilen vergiler intikal eden malların VUK' na göre bulunacak değerlerine göre tamamlanır.

\subsubsection{Illk Tarhiyatın Tahakkuku}

Mükelleflerin ilk tarhiyatla ilgili verginin; beyannamenin elden alınmasını müteakip tahakkuk fişinin hemen düzenlenip "mükellef" nüshasının ilgiliye verildiği; beyannamenin alınmasını takiben tahakkuk fişinin hemen düzenlenerek elden verilmesinin mümkün olmadığı ve beyanname posta ile gönderilmiş ise, vergi dairesince alındığı tarihten itibaren 15 günlük sürenin bittiği gün tahakkuk eder (Arica (a), 2010:122).

\subsubsection{Nihai Tarhiyat}

Veraset ve intikal vergisini ilgilendiren işlemler, mükelleflerin yalnızca beyannamelerini vermekle sınırlı olmayıp, söz konusu beyanlara yapılan ilk tarhiyat sonrasında Takdir Komisyonları vasıtasıyla gerçekleştirilen nihai tarhiyat sonucunda ödenmesi gereken vergilerin tutarı belli olmaktadır (Alptürk, 2003:5). Bu şekilde yapılan tarhiyat ile, ilk tarhiyata esas olan değerler ile vergi idaresinin bulduğu değerler arasındaki fark üzerinden ikinci (ikmalen) tarhiyat yapilır (Pehlivan, 1999:349).

Illk tarhiyat işlemi sırasında vergi aslına bağı herhangi bir ceza uygulaması söz konusu değilken, kesin tarhiyat sırasında ceza uygulaması da mümkün olabilmektedir (Arıca(b), 2010:114).
Intikal konusunu oluşturan mallar için, ilk tarhiyat ve nihai tarhiyat aşamalarında farklı değerleme ölçüleri belirlenmiştir. Bu durumu ortadan kaldırmak için, idare ile mükellef malları değerlemede aynı değerleme ölçütlerini seçebilir veya ortak tarhiyat için bilirkişilik kurumundan faydalanılacak bir düzenleme yürürlüğe konabilir. Miktar olarak küçük terekeler için bir kişilik, büyük terekeler için ise üç kişilik bir heyet kurularak ve bilirkişilik mekanizmasının işlerliği sağlanarak, vergi matrahının bir defada tespit edilmesi gerçekleşebilir. Böylece vergi tarhiyatında iki başlılık ortadan kalkarak oluşacak olan tarhiyat farklılıklarının da önüne geçilmiş olur. Aynı zamanda verginin mükellef ve idare tarafından ayrı ayrı tespit edilmesi nedeniyle ortaya çıkacak olan maliyet, emek ve zaman kaybı önlenmiş olur.

\subsection{Değerleme Günü, İndirilebilecek Borçlar, Masraflar ve İhtilaflı Borçlar}

V.I.V.K.' nun 11. maddesinde bu vergiye konu olacak malların değerleme günü, miras yoluyla meydana gelen intikallerde mirasın açıldığı, diğer suretle olan intikallerde malların hukuken iktisap edildiği gündür.

Ancak bu kanun maddesi çeşitli sorunları da beraberinde getirmiştir: Sağlar arası intikallerde, bir mükellefe intikal eden herhangi bir varlık dolayısıyla ortaya çıkan vergi borcu, yıllar sonra tespit edilirse, vergiye esas matrah için malların elde edildiği gün göz önüne alınır ve yıllar itibariyle malın değerinde meydana gelen değer kaybı göz ardı edilir. Bu durum, vergiye konu malları gecikmeli beyan eden ya da malları gecikmeli tespit edilen mükellef lehinedir. Ayrıca, vergi beyanını zamanında yapan vergi mükellefini de cezalandırmaktadır. Yıllar sonra beyan edilen mallar için devletin elde ettiği gelir, enflasyonist bir ortamda değer kaybına uğrayacağından bu durum da devletin gelir kaybına neden olmaktadır.

Örneğin; spor totodan 01.01.2005 tarihinde kazandığı ikramiyesini 01.01.2013 tarihinde beyan eden mükellef için mükellefiyet, beyanname verdiği tarih olan 01.01.2013 tarihinde başlayacağından gecikme faizi ve vergi ziyaı kabahati talep edilemeyecektir. Mükelleften sadece değerleme günü olan 01.01.2005 tarihinde kazandığı ikramiye üzerinden hesaplanan vergi aslı istenebilecektir. V.I.V.K. 'nda değerleme gününün "malların hukuken iktisap edildiği gün" şeklinde tanımlanması nedeniyle ikramiye miktarının yeniden değerlemeye tabi tutularak 01.01.2013' deki değerinin bulunması da söz konusu olmayacaktır. Oysa aynı mükellefin böyle bir ikramiye kazandığının idarece tespit edilmesi durumunda tespit tarihinde mükellefiyet başlayacak ve gecikme faizi işleyecektir. 
Idarenin intikallerden geç bilgi edinmesi nedeniyle ortaya çıkacak gelir kaybının önüne geçilmesi için, intikale konu malın/paranın değerinin yıllar itibariyle değişebileceği hususunun dikkate alınması gereklidir. Değer tespiti konusunda endeksleme yöntemi (Güçlü, 2009:83) geliştirilebileceği gibi, malların bugünkü sigorta değerlerinin de esas alınabileceği bir düzenleme yapılması gerekir. Değerleme yapılırken, malların hukuken iktisap edildiği günkü değeri yerine, verginin hesaplandığı günkü değerinin dikkate alınması hakkaniyete daha uygun düşecektir. Değer tespitine esas alınacak unsurlara örnek vermek gerekirse; intikale konu olan gayrimenkul ise, gayrimenkulün bugünkü emlak vergisine esas değeri veya DASK (Doğal Afet Sigortaları Kurumu) değeri, menkul mal ise, örneğin aracın kasko değeri veya hisse senedinin borsada kayıtlı değeri, yine bir menkul mal olan para intikalleri için, enflasyon oranı dikkate alınarak yapılan endeksleme yöntemi ile bulunan değeri olmalıdır.

V.I.V.K.' nun 12. maddesinde ise indirilebilecek borçlar ve masraflar belirtilmiştir. İktisap edilen malların değerlerinden veya değerleri toplamından aşağıda yazılı borçlar ve masraflar, beyannamede gösterilmek şartıyla indirilir: Veraset yoluyla meydana gelen intikallerde murisin delil göstermeye elverişli belgelere dayanan borçları ile vergi borçları; diğer suretle iktisaplarda intikal eden malın aynına bağlı olan borçlarla vergi borçları (Şu kadar ki, hibe eden hibe ettiği mala bağıı olan borçları kendi üzerine almış veya öyle taahhüt etmiş ise bu borçlar nazara alınmaz); Türkiye Cumhuriyeti tabiiyetinde olan şahıslara ait mallardan yabancı memleketlerde bulunanlara ait olan borçlar ve yabancı memleketlerde bu mallar dolayısıyla alınan veraset ve intikal vergileri (tevsik edilmek şartıyla); fıkrasında yazılı borçlar ile veraset ve intikal vergileri, beyannamede gösterilen bu kabil malların değerini geçemez.); Cenazenin hazırlanması ve gömülmesi için yapılan masraflar indirilebilir.

V.I.V.K.' nun 13. maddesinde ihtilaflı borçlar hakkında açıklamalara yer verilmiştir. Ölen kimsenin sağlığında icra dairesine veya mahkemeye intikal etmiş ve takip edilmekte olan alacak ve borçlarının beyannamede açıkça gösterilmesi şarttır. Bu alacak ve borçların vergileri tahakkuk ettirilerek tahsilleri icra dairesi veya mahkemenin vereceği kesin karar veya hüküm neticesine göre tecil olunur. Şu kadar ki, bu tecil her ne suretle olursa olsun, hiçbir zaman on seneden fazla devam edemez. Mükellefler her altı ayda bir icra ve dava vaziyetlerini bir dilekçe ile vergi dairesine bildirmeye mecburdurlar. Bu bildirim yapılmadığı takdirde tecil olunan vergiler derhal tahsil edilir. Tecil olunan vergilerin ait olduğu davalar tecil müddetinden sonra neticelenecek olursa mükelleflerin müracaatı üzerine ve belli olacak hale göre gereken düzeltmeler yapılır ve fazla alınmış vergiler varsa, terkin ve sahiplerine geri verilir.

\subsection{Verginin Tarhı ve Oranlar}

V.I.V.K.' nun 14. maddesinde, vergi, mükellef tarafından verilen beyanname üzerine tarh olunur, denilerek beyanname üzerinden tarhın gerçekleştirildiği belirtilmiştir.

Veraset ve intikal vergisi, Tablo 1'den de izleneceği üzere, aşağıda yazılı oranlar üzerinden alınmaktadır.

Tablo 1: 2013 Veraset ve İntikal Vergisi Tarifesi

\begin{tabular}{|l|c|c|}
\hline \multicolumn{1}{|c|}{ Matrah } & $\begin{array}{c}\text { Veraset Yoluyla } \\
\text { İntikallerde } \\
\text { Vergi Oranı (\%) }\end{array}$ & $\begin{array}{c}\text { İvazsız } \\
\text { İntikallerde } \\
\text { Vergi Oranı (\%) }\end{array}$ \\
\hline İlk 190.000 TL için & 1 & 10 \\
\hline $\begin{array}{l}\text { Sonra gelen 430.000 TL } \\
\text { için }\end{array}$ & 3 & 15 \\
\hline $\begin{array}{l}\text { Sonra gelen 940.000 TL } \\
\text { için }\end{array}$ & 5 & 20 \\
\hline $\begin{array}{l}\text { Sonra gelen 1.800.000 } \\
\text { TL için }\end{array}$ & 7 & 25 \\
\hline $\begin{array}{l}\text { Matrahın 3.360.000 TL'yi } \\
\text { aşan bölümü için }\end{array}$ & 10 & 30 \\
\hline
\end{tabular}

( Kaynak: 7338 sayılı Veraset ve İntikal Vergisi Kanunu.)

Veraset ve intikal vergisi değer esasına göre düzenlenmiştir ve artan oranlı yapıdadır (Akdoğan, 2003: 380). Ancak sadece artan oranlı vergi tarifesi demek, yanlış olacaktır. Veraset ve intikal vergisi, çifte artan oranlı vergi tarifesi esasına dayanmaktadır. V.I.V.K., oranların matraha göre artmasının yanı sıra veraset yoluyla intikal veya veraset dışında herhangi bir yolla ivazsız intikal oluşa göre de ayrıca değişmesini kabul etmek suretiyle, çifte artan oranlılık esasını getirmiştir (Öncel, Kumrulu, Çağan, 2003:383).

Bir şahsa ana, baba, eş ve çocuklarından (evlatlıktan evlat edinenlere yapılan ivazsız intikaller hariç) ivazsız mal intikali halinde vergi, ivazsız intikallere ilişkin tarifede yer alan oranların yarısı uygulanarak hesaplanır.

5602 sayılı Kanunda tanımlanan şans oyunları ile gerçek ve tüzel kişilerce düzenlenen yarışma ve çekilişlerde kazanılan ikramiyelerde oran \% 10 olarak uygulanır. İkramiyenin ayni olarak ödenmesi halinde, fatura değeri esas alınır.

\subsection{Vergiye Karşııık Alınacak Teminat ve İhtiyat} Tedbirleri

V.I.V.K.' nun 17. maddesinde vergiye karşı alınacak teminatlara ilişkin açıklamalara yer verilmiştir. Buna göre; Amme idare ve müesseseleri, bankalar, bankerler, kasa kiralayanlar, sigorta şirketleri, diğer şirket ve 
müesseseler, mahkemeler ve icra daireleri hak sahiplerine bu verginin konusuna giren herhangi bir işlem dolayısıyla para ve senet verebilmek için önceden verginin ödenmiş olduğuna dair vergi dairesinden verilmiş bir tasdikname talep ederler. Ancak, hak sahiplerinin yukarıdaki türden bir belgeyi ibraz edemedikleri durumlarda da, belirli koşullarla intikal konusu mallara tasarruf edebilmelerine imkan tanınmış bulunmaktadır (Arıca,2008:72).

Tasdikname ibraz etmeyen hak sahiplerinin hakla$\mathrm{rl}$, veraset yoluyla intikallerde $\% 5$, ivazsız intikallerde \% 15 oranında vergi karşılığı olarak tevkifat yaptıktan sonra, bakiyesini verebilirler. Tevkifatı yapanlar, tevkif ettikleri parayı en geç bir hafta içinde bulundukları yerin mal sandığına yatırmaya ve keyfiyeti bağlı bulundukları vergi dairesine yazı ile bildirmeye mecburdurlar.

V.I.V.K.' nun 17. maddesine istinaden yapılacak stopajın murisin en son ikametgahının bağlı olduğu vergi dairesine yatırılması gereklidir.

V.I.V.K.' nun 18. maddesinde, veraset ve intikal vergisi matrahına girmesi gereken malların kaçırılacağını anlatır karinelerin bulunduğu hallerde vergi dairesince Türk Medeni Kanunu' nun 590. maddesinin 3 numaralı fıkrasına ${ }^{1}$ istinaden tereke defterinin yapılması istenebilir, denilerek veraset ve intikal vergisinin ihtiyat tedbirleri hakkında bilgi verilmektedir.

\section{9. Ödeme Zamanı}

V.I.V.K.' nun 19. maddesinde veraset ve intikal vergisinin ödeme zamanına ilişkin bilgiler bulunmaktadir.

Veraset ve intikal vergisi tahakkukundan itibaren 3 yılda ve her yıl mayıs ve kasım aylarında olmak üzere iki eşit taksitte (gerçek ve tüzel kişilerce düzenlenen yarışma ve çekilişlerde kazananlara ödenecek ikramiyeler ile 5602 Sayılı Kanunda tanımlanan şans oyunları dolayısıyla dağıtılacak ikramiyelerden kesilen vergiler beyanname verme süresi içinde) ödenir. Bu ödeme kolaylığı ve oldukça uzun süre, vergiyi gerçek bir servet vergisi olmaktan alıkoymaktadır (Öncel, Kumrulu, Çağan, 2003:387). Kanımızca vade süresinin dolayısıyla taksit sayısının azaltılması bu verginin tahsilinde paranın aşınma değerinin de azalması yönünde katkı sağlayacaktır.

\subsection{Mükellefiyetin Başlangıcı}

Mükellefiyetin başlaması için, vergiyi doğuran olayın gerçekleşmesi gerekmektedir. Veraset vergisinde vergiyi doğuran olay, ölüm olayının gerçekleşmesi veya kişinin gaipliğine karar verilmesidir². İvazsız intikallerde ise, vergiyi doğuran olay, özellikle hukuki bir işlemin olgunlaşması ile gerçekleşmektedir.
V.I.V.K.' nun 20. maddesinde, mükellefiyetin başlama tarihleri verilmektedir. Veraset ve intikal vergisi mükellefiyeti: Beyanname verildiği takdirde, beyannamede gösterilen mallar için beyanname tarihinde; verilen beyannamede gösterilmeyen mallar ile beyanname verilmeyen hallerde intikal eden malların idarece tespit olunduğu tarihte; terekenin tahriri ${ }^{3}$, defter tutma veya resmi tasfiye hallerinde mahkemece bu muamelelerin ikmal edildiği tarihte başlar.

Yukarıda verilen üç maddenin ikinci ve üçüncüsünde belirtilen mükellefiyetin başlama tarihlerinin, günümüz şartlarında önemli ölçüde bir adaletsizliğe yol açtığı düşünülmektedir. Söz konusu hükümler verginin zamanaşımına uğrama riskini azaltmakla birlikte, başka kayıplara da neden olacak niteliktedir (Güçlü, 2009:74). Bu kayıplardan en önemlisi, paranın değerindeki aşınmadır.

Bu düzenlemenin tabii bir sonucu olarak; veraset ve intikal vergisinde zamanaşımının başlangıcı, ölüm veya ivazsız surette iktisap tarihi değil; beyanname ile bildirilen mallar için beyannamenin verildiği, beyan edilmeyen mallar için bu malların idarece tespit edildiği tarih olmaktadır, diyebiliriz (Arıca, 2008:73). Intikal tarihinden çok uzun bir süre sonra tespit olunan mallar için herhangi bir ceza uygulaması söz konusu olmadığı için, bu durum iyi niyetli mükellefleri cezalandırma olarak görülmektedir. Diğer taraftan, verginin gecikmeli de olsa tahsili, tahsilat gelirlerinin artması bakımından önem taşımaktadır.

Örneğin, 1980 yılı ocak ayında kendilerine veraset yoluyla aynı nitelikte ve aynı değerde mal intikal eden Bay (A) ve (B)' den Bay (A) beyannamesini süresi içinde vergi dairesine vermiş ve hesaplanan toplam $300 \mathrm{TL}$ vergiyi ödemiştir. Aradan geçen 28 yıl sonra her iki kişiye de intikal eden servetin değeri yaklaşık 2800 kat artmıştır. Dolayısıyla Bay (A)' nın ödediği verginin alım gücü değeri de yaklaşık 2800 kat artmış olmaktadır. Bay (B) ise beyannameyi 2008 yılı ocak ayı içinde vergi dairesine vererek o da aynı değerler yani intikal eden servetin 28 yı önceki değerleri üzerinden ve aynı vergi tarifesi esas alınarak hesaplanan sadece 300 TL vergiyi ödemiştir (Akarslan, 2008:4).

Veraset ve intikal vergisinde mükellefiyetin; beyannamede gösterilmeyen mallar ile beyanname verilmeyen hallerde intikal eden malların idarece tespit olunduğu tarihte yani gecikmeli olarak başlamasına, mükellefin beyan görevini zamanında yerine getirmemesi neden olmaktadır. Ayrıca, idarenin mükellefiyeti zamanında tespit etmemesi nedeniyle inmal veya kusuru da bulunmaktadır. Buradan hareketle, mükellefiyetin geç tespit edilmesi nedeniyle vergi alacağının gecikmeli olarak tahsil edilmiş olması dola- 
yısıyla ortaya çıkacak paranın zaman değeri kaybının telafi edilmesine yönelik olarak gecikme faizi uygulaması yerinde olacaktır.

Yukarıdaki örnekte, mükellefin 1980 yılında ödemesi gereken 300 TL tutarındaki vergiye 2008 yılına kadar yürürlükteki gecikme faizi üzerinden faiz işletilerek paranın bugünkü değerinin korunması sağlanmış olacaktır.

\subsection{Gaibin Ortaya Çıkması}

V.I.V.K.' nun 21. Maddesinde, hem gaip mirasçı hem de gaip murisin ortaya çıkması durumlarında yapılacak işlemlere ilişkin açıklamalara yer verilmiştir.

Gaip mirasçının ortaya çıkması durumunda, gaip mirasçının ortaya çıkması dolayısıyla önceden tahakkuk eden veraset ve intikal vergisinin değişimi gerektiği takdirde, ortaya çıkan mirasçının vereceği beyannameye veya vergi dairesince yapılacak idari soruşturmaya göre sabit olacak matrah üzerinden vergi düzeltilir.

Gaip murisin ortaya çıkması durumunda, nüfustaki ölüm kaydının silinmesinden sonra, önceden alınmış olan vergiler talep üzerine mükellefe geri verilir.

\subsection{Mirasçılıkları Hükmen Sabit Olanlar}

V.I.V.K.'nun 22. maddesinde, veraset ve intikal vergisinin ödenmesinden sonra bir malın vergi verenden başka bir şahsa ait olduğu mahkeme kararıyla sabit olur ve ilamın kesinleşmesinden sonra bir sene içinde müracaat edilirse fazla alınan vergi, verene iade ve hakiki mükelleften tahsil olunur, denilmektedir.

Veraset ve intikal vergisi, müterakki tarife yapıs-na sahip olduğundan mahkeme ilamı ile mirasa sahip olan kişi için vergi hesaplanırken, önceden kendisinden vergi alınan şahsın vergisi ise düzeltilir. Bütün bu işlemler yıllar sonra dahi yapılsa, intikalin gerçekleştiği tarihteki oranlar ve istisna tutarları dikkate alınır (Maç, Jamali, 2012:2).

\subsection{Bankalardaki Kiralık Kasaların İçindekilerinin Tespiti}

V.I.V.K.' nun 23. maddesinde, bankalar gözetimindeki kiralık kasa sahiplerinden birinin ölümü halinde (sulh hakimi tarafından yapılacak tespit hariç) vergi dairesinin yetkili bir memuru hazır bulunmadıkça kasanın açılmasına ve bu memur huzurunda tespit edilmedikçe, içindekilerin mirasçıları veya kanuni temsilcileri veya vekilleri tarafından alınmasına müsaade edemezler.

Söz konusu kanuni hüküm karşısında ortaya çıkan sorunlar da mevcuttur (Aydın, 2010:56). Murise ait kiralık kasaların varlığından ilgili vergi dairelerinin beyan döneminden uzun bir süre sonra bilgi sahibi olmaları ile karşılaşılabilmektedir. Bu durum özellikle mirasçılar açısından vergisel olarak sorunların ortaya çıkmasına neden olmaktadır.

Bankalarda bulunan kiralık kasaların ortaklaşa kiralanması veya kiralayan tarafından bir başka şahsa vekalet verilmesi durumunda uygulanacak yaptırıma ilişkin olarak V.i.V.K.' nda bir düzenleme mevcut değildir. ViVK' na; ölen kişiye ait kiralık kasanın ortaklaşa kullanılması ya da vekaleten kullanılması durumunda, murisin ölüm tarihinden sonra yapılan işlemler sonucu kaçırılan veraset ve intikal vergisi için bu kişilere rücu edilebileceği yönünde bir düzenleme eklenmesi söz konusu olabilir. Bir başka çözüm önerisi olarak şu şekilde bir düzenleme yapılabilir; bankalar ile nüfus dairelerinin iletişim halinde olması ile ölüm olayı bankalara hemen bildirilebilir ve bankalarca ortaklaşa kiralık kasalara ilişkin işlemlerin sağ kalan ortaklar için vergi ödendiğine ilişkin belgeler sunuluncaya kadar dondurulması yöntemine gidilebilir, bu yönde bankalara sorumluluk yüklenebilir.

\subsection{Veraset ve İntikal Vergisine İlişkin Diğer} Sorunlar

Yukarıda açıklaması yapılan kanun maddeleri ve uygulamada karşılaşılan sorunların dışında ek olarak ortaya çıkan sorunlar da mevcuttur.

\subsubsection{Banka Hesaplarının Dikkate Alınması ile İlgili Sorunlar}

Miras bırakan kişinin yani murisin, banka hesabında bulunan vadeli hesabı veya hesapları, faiz alacakla$\mathrm{rl}$, ortak hesaba sahip olan kişilerden birinin vefat etmesi durumunda diğer hesap sahiplerine düşen pay ve bu payların veraset ve intikal vergisinin kapsamına girip girmediği konusu, aşağıdaki açıklamalarla açıklığa kavuşacaktır (Güleç,2013:3).

- Veraset ve intikal vergisinde vergiyi doğuran olayın ölüm tarihindeki mevcutları kapsaması nedeniyle miras bırakanın ölüm tarihine kadar hesaplanan mevduat faizi / kar payı veraset ve intikal vergisine konu edilecektir. Ölüm tarihinden sonra hesaplanan mevduat faizi / kar payı için veraset ve intikal vergisi aranılmayacağından bankalardan mirasçılara ait vadeli hesaplardaki paraları ölüm tarihi itibariyle bildirmeleri istenecek, bankalar da gerektiğinde yapacakları kesintiyi bu tutar üzerinden yapacaktır.

- Hesaplarda bulunan yabancı paralar içinse, değerleme gününde (miras bırakanın ölüm tarihinde) Bakanlıkça ilan edilen kurlarla, kur ilan edilmediği durumlarda Türkiye Cumhuriyet Merkez Bankası' nca ilan edilen döviz alış kuru esas alınması suretiyle değerleme yapılacaktır. 
- Ortak hesaplarda ise murislerden birinin ölümü halinde ölen kişinin hissesine isabet eden kısmın, mirasçılar tarafından ilgili vergi dairesine beyan edilerek veraset ve intikal vergisine tabi tutulması gerekmektedir.

\subsubsection{Banka Hesabına Ortak Etme Durumu}

Var olan bir banka hesabını bir kişi, eşi, çocuğu, annesi veya herhangi bir akrabası ile ortak kullanmak isteyebilir. Bu durumda veraset ve intikal vergisi karşısındaki yükümlülüğü ortak olduğu kişi ile birlikte değişebilmektedir. Bu durumu bir örnekle açıklayacak olursak (Kızılot(b), 2013):

Örneğin; (A) bankasında 600.000 TL mevduata sahip olan bir kişi, eşini de bu hesaba ortak etmiştir. Bu durumda eşine 300.000 TL bağışlamış olur ve ivazsız intikal üzerinden vergilendirilir. Verginin oranı, hesaba ortak edilen kişinin kim olduğuna göre değişmektedir. Anne, baba, eş ve çocuklarda var olan oranın yarısı; diğerlerinde normal oran uygulanmaktadır.

\subsubsection{Vergi Sürecinin Ağır İşlemesi Sorunu}

Vergi idaresince veraseten kalan malların vergisinin zamanında ödenmesi için şöyle bir sistem geliştirilmesi mümkündür. Nüfus idaresinden her ay vergi dairelerine, gerçekleşen ölüm olaylarını, ölenin vukuatlı nüfus kimlik bilgilerini elektronik ortamda göndermelerine yönelik düzenleme yapılmalıdır. Ardından, gelen bilgiler çerçevesinde, Tapu Kadastro Genel Müdürlüğü' nden, kara, hava ve deniz motorlu taşıtlarının bağlı bulunduğu tescil birimlerinden, Türkiye Bankalar Birliği' nden, Borsa İstanbul' dan yapılacak araştırmalarla ölen kişinin malvarlığının tespit edilmesi sağlanabilir. Daha sonra nüfus idaresinden gelen vukuatlı nüfus kimlik bilgilerinden yola çıkılarak, veraseten kendisine mal kalan kişilerin vergilendirilmesi yoluna gidilebilir. Ancak burada belirtilmesi gereken bir husus bulunmaktadır. Her ne kadar yasa ile bankalar ölen kişiye ait mevduat hesaplarından mirasçılara ödeme yapııııken veraset ve intikal vergisinin ödenip ödenmediğinin bilgilendirilmesini istemek ya da stopaj yöntemi ile vergi kesmek zorunda iseler de, ortak banka hesaplarında taraflar münferit olarak para çekmeye yetkililerse, ölüm olayını bildirmeden, hayatta kalan ortak parayı çekebilir. Bu durumda da verginin tahsili konusunda bankanın takip ve kontrol olanağı kalmadığından, verginin tahsil olanağı ortadan kalkabilir.

Miras yoluyla kalan malvarlığının tespiti, teknik olarak daha kolay olmakla birlikte, ivazsız intikallerde, bağışlanan kişinin beyanname vermemesi durumunda daha zordur. Çünkü bir kişinin bağışlanan mala kendisinin de sahip olabileceği göz önüne alındığında, ödeme yapmadan bağış yoluyla edindiği hususu ancak vergi inceleme elemanlarınca tespit edilebilecek bir durumdur. Bağışlanan kişinin herhangi bir gelire sahip olmaması, herhangi bir yerde çalışıyor olmaması, bu mallara bağış yoluyla sahip olduğu yönünde önemli bir gösterge olabilir. Ancak yine de gerçekten bir intikalin ivazsız olup olmadığının tespiti zaman zaman kolay olmayabilir. Burada vergi inceleme elemanlarının sayısının arttırılması, bir önlem olarak değerlendirilmelidir.

\subsection{Veraset Ve Intikal Vergisinde Beyan} Sistemi Yerine Tevkifat Önerisi

Veraset ve intikal vergisi beyan sistemine dayalı bir vergidir ve yukarıdaki çözüm önerileri beyan sistemi dikkate alınarak yapılmıştır. Bütün bunların dışında bir diğer öneri olarak veraset ve intikal vergisinin tarh, tahakkuk ve tahsilinde beyan sisteminin kullanılmasının yerine tevkifat yönteminin uygulanması verginin alınmasını kolaylaştırmak üzere getirilebilecek bir sistem olarak değerlendirilebilir. Tevkifat yönteminde, vergiye esas değer üzerinden tek bir oran uygulaması söz konusu olduğu için, artan oranlı tarifeye göre daha adaletsiz gibi görünse de; tek oranlı bir tarifede matrah arttıkça gizli bir artan oranlıık ortaya çıktığından, bu uygulama vergi adaleti açısından olumsuz olarak değerlendirilmeyebilir.

Bu yöntemde, vergi sorumlularının belirlenmesi konusunda bir düzenleme yapılmalıdır. Örneğin, para intikallerinde bankaların yetkili memurları tarafından veraset ve intikal vergisinin ödendiğine dair bir belge istenmesinin yerine paranın intikali sırasında vergi kesintisi yapılması (halen verasette \% 5 oranında tevkifat yapılmasına ilişkin yasal düzenleme mevcuttur); tapu memurları tarafından gayrimenkul intikali sırasında vergi kesintisi yapılması; motorlu taşıtların intikali sırasında tescil memuru tarafından vergi kesintisi yapılması; menkul mallar için menkul kıymet alım-satım yapmaya yetkili kurumlar tarafından vergi kesintisi yapılması ve vergi dairelerine parasal olarak aktarılması hem vergi dairelerinin hem de vergi mükelleflerinin verginin tahsili için harcadıkları emek, zaman kaybının önlenmesi yanı sıra, vergi kayıp ve kaçağının azaltılmasında da fayda sağlayabileceği düşünülmektedir.

\section{SONUÇ}

Servet vergilerinin önemli bir türü olan veraset ve intikal vergisinin dünya üzerindeki tarihi, çok eskilere dayanmaktadır. Illk uygulanan veraset ve intikal vergisi, M.Ö. 7. yüzyılda Mısır' dadır. Daha gelişmiş bir veraset vergisi ise, M.Ö. 1. yüzyılda Roma İmparatorluğu zamanında görülmüştür. 
Türkiye' deki veraset ve intikal vergisi tarihini, cumhuriyet öncesi ve sonrası dönem olarak ikiye ayırmak mümkündür. Cumhuriyet öncesi yani Osmanlı Devleti döneminde ferağ, intikal ve tahrir harçları adı altında tahsilatlar yapıldığı görülmektedir. Cumhuriyet sonrası dönemde, ilk veraset ve intikal vergisi, 1926 yılında çıkarılan 797 sayılı V.I.V.K.' nda görülmüştür. Veraset ve intikal vergisinin günümüzdeki şeklinin temelini ise, 1959 yılında uygulamaya geçen 7338 sayılı Kanun oluşturmuştur. Bu tarihten sonra kanun maddelerinde çeşitli değişiklikler yapılmasına rağmen, köklü bir değişiklik söz konusu olmamıştır. Veraset ve intikal vergisinin toplam vergi gelirleri içindeki payına bakıldığında, yıllar itibariyle çok fazla bir değişikliğin olmadığı görülmektedir. Bunun çeşitli sebepleri vardır. En önemli sebeplerden biri, veraset ve intikal vergisinin tespit edilmesindeki güçlüktür. Bunun yanında, istisna ve muafiyetlerin geniş yer tutması, verginin değerleme gününün miras yoluyla intikallerde mirasın açıldığı, diğer ivazsız intikallerde ise, malların hukuken iktisap edildiği gün olması dolayısıyla yıllar sonra ortaya çıkan vergi borcunun aşınma değerinin göz önüne alınmaması, çift başlı tarhiyatın söz konusu olması verginin tahsil miktarını düşüren sebeplerdir.

Medeni Kanun ile ViVK, arasındaki mirası reddetme konusunda ölüm tarihinin tespiti hususundaki farklılık mükellefin mirası reddetme hakkını elinden almakta olup, her iki kanun arasında uyum sağlanmalı, Medeni Kanun' da düzenlendiği gibi, mirası reddetme konusunda ölümün öğrenildiği tarih esas alınmalıdır.

Vergi matrahının mükellef ve idarece ayrı ayrı tespit edilmesi, vergiyi karmaşık bir hale getirdiğinden, idare ile mükellef malları değerlemede aynı değerleme ölçütlerini seçmeli ya da ortak tarhiyat için bilirkişilik kurumundan faydalanılacak bir düzenleme yürürlüğe konmak suretiyle tarhiyat farklılıklarının yol açtığı maliyet, emek ve zaman kaybı da önlenmiş olacaktır.

Söz konusu vergi için değerleme günü, miras yoluyla intikallerde mirasın açıldığı, diğer ivazsız intikallerde ise, malların hukuken iktisap edildiği gündür.
Ancak, yıllar sonra beyan edilen ve idarece de tespit edilemeyen hallerde gecikmeli beyan veren ya da malları gecikmeli tespit edilen mükellef lehine ve devlet aleyhine bir durum söz konusu olacaktır.

İdarenin intikallerden geç bilgi edinmesi nedeniyle ortaya çıkacak gelir kaybının önüne geçilmesi için, intikale konu malın değerinin yıllar itibariyle değişebileceği hususunun dikkate alınması gereklidir. Değer tespiti konusunda endeksleme yöntemi geliştirilebileceği gibi, malların bugünkü sigorta değerlerinin de esas alınabileceği bir düzenleme yapılması gerekir. Değerleme yapılırken, malların hukuken iktisap edildiği günkü değeri yerine, verginin hesaplandığı günkü değerinin dikkate alınması, hakkaniyete daha uygun düşecektir. Verginin 3 yıl ve 6 taksit olan ödeme süresinin azaltılması, paranın aşınma değerinin de azalması yönünde katkı sağlayacaktır.

Veraset ve intikal vergisinde mükellefiyetin; verilen beyannamede gösterilmeyen mallar ile beyanname verilmeyen hallerde intikal eden malların idarece tespit olunduğu tarihte yani gecikmeli olarak başlamasına, mükellefin beyan görevini zamanında yerine getirmemesi neden olmaktadır. Ayrıca, idarenin mükellefiyeti zamanında tespit etmemesi nedeniyle ihmal veya kusuru da bulunmaktadır. Buradan hareketle, mükellefiyetin geç tespit edilmesi nedeniyle vergi alacağının gecikmeli olarak tahsil edilmiş olması dolayısıyla ortaya çıkacak paranın zaman değeri kaybının telafi edilmesine yönelik olarak gecikme faizi uygulaması yerinde olacaktır.

Türkiye' de veraset ve intikal vergisinin dayanakları; ilk önce Anayasa' nın "sosyal devlet" ilkesi ve sonrasında yine Anayasa' nın "herkesin mali gücüne göre vergilendirilmesi" ibaresidir. Vergi gelirleri içerisinde düşük bir paya sahip olan veraset ve intikal vergisinin, neden hala uygulanmakta olduğunun cevabı ise; servetin de bir ödeme gücü unsuru olmasının yanı sıra, vergi adaleti ve gelir dağılımında adaleti sağlamaya yardımcı bir vergi türü olmasıdır. 


\section{SON NOTLAR}

Türk Medeni Kanunu' nun söz konusu 590. maddesinin 3. fikrasında; sulh hakimi, mirasçılardan veya ilgililerden biri, ölüm tarihinden başlayarak bir ay içinde istemde bulunursa, terekenin defterinin tutulmasina karar verir ve defter tutma işlemi gecikmeksizin tamamlanır.

${ }^{2}$ Gaiplik kararı, Türk Medeni Kanunu 32 - 35. maddeleri arasında düzenlenmiştir. Ölüm tehlikesi içinde kaybolan veya kendisinden uzun zamandan beri haber alınamayan bir kimsenin ölümü hakkında kuvvetli olasılık varsa, hakları bu ölüme bağlı olanların başvurusu üzerine mahkeme bu kişinin gaipliğine karar verebilir. Gaiplik kararının istenebilmesi için, ölüm tehlikesinin üzerinden en az bir yıl veya son haber tarihinin üzerinden en az beş yıl geçmiş olması gerekir. Gaipliğine karar verilecek kişi, ilân süresi dolmadan ortaya çıkar veya kendisinden haber alınırsa ya da öldüğü tarih tespit edilirse gaiplik istemi düşer.

${ }^{3}$ Tahrir: Kaydetme, yazma.

\section{KAYNAKLAR}

Akarslan, M. (2006) "Usulsüzlük ve Vergi Ziyai Cezalarının Veraset ve İntikal Vergisi Yönünden UygulamasıII" http:/www.yaklasim.com/,(10.10.2013).

Akarslan, M. (2008) "Veraset ve İntikal Vergisi Beyannamelerinin Geç Verilmesinde Ölüm Olayını Bildirmekle Yükümlü Olanların Sorumluluğu”, Yaklaşım Dergisi, 182.

Akdoğan, A. (2003) Türk Vergi Sistemi ve Uygulaması, 4. Baskı, Ankara, Gazi Kitabevi.

Aksoy, Ş. (1991) Vergi Hukuku ve Türk Vergi Sistemi, 3. Baskı, İstanbul, Filiz Kitabevi.

Alptürk, E. (2003) "Veraset ve İntikal Vergisi Yönünden Ticari Servet Unsurlarının Değerlemesi” http://www. yaklasim.com/, (01.08.2013).

Arıca, M.N. (2008) "Veraset ve İntikal Vergisinin Uygulamasında İhtiyat Tedbirleri-2" http://www.maliyesigortayor.com.tr/maliyesi/hata.php?hata=2,(05.07.2013).

Arıca, M.N. (2010a) "Veraset ve İntikal Vergisi Uygulamasında 'İlk Tarhiyat' ve 'Nihai Tarhiyat' İşlemleri-2” (05.07.2013).

Arıca, M.N. (2010b) "Veraset ve İntikal Vergisi Uygulamasında 'İlk Tarhiyat' ve 'Nihai Tarhiyat' İşlemleri-3” http://www.maliyesigortayor.com.tr/maliyesi/hata. php?hata=2, (05.07.2013).

Arıca, M.N. (2010c) "Veraset ve İntikal Vergisi Beyanname Verme Yükümlülüğünün Hiç Yerine Getirilmemesi Ya Da Kanuni Beyan Süresinin Bitiminden Sonraki Farklı Zamanlarda Gecikmeli Olarak Yerine Getirilmesi Hallerinde Uygulanabilecek Usulsüzlük Cezaları” Maliye ve Sigorta Yorumlar Dergisi, 544.

Aydın, F. (2010) "Bankalardaki Kiralık Kasaların Veraset ve İntikal Vergisi Kanunu Açısından Değerlendirilmesi" http://www.vergisorunlari.com.tr/ (12.09.2013).

Bilici, N. (2010) Vergi Hukuku Genel Hükümler Türk Vergi Sistemi, 23.Baskı, Ankara, Seçkin Yayıncılık.

Borsa Terimleri Sözlüğü (2013) http://borsa.ku.edu. tr/dokumanlar/Borsa\%Sozlgu.pdf, (10.03.2013).

Cremer, H. ve Pierre, P. (2003) "Wealth Transfer Taxation: A Survey”, Cesifo Working Paper Series, No:1061.
Çelik, G. (995) Servet ve Harcama Vergileri, Ankara, Seçkin Yayınevi.

Gale, G.W.J. (2001) "Slemrod, Rethinking The Estate and Gift Tax: Overview, NBER Working Paper Series, No: 8205.

Güçlü, S. (2009) "Veraset ve İntikal Vergisinde Mükellefiyet, Değerleme Günü ve Gecikme Faizi Uygulamalarının Etkileri” http://www.vergisorunlari.com.tr/, (12.09.2013).

Güleç, S. (2013) "Veraset ve İntikal Vergisinde Banka Hesapları Nasıl Dikkate Alınacak" http://www.yaklasim. com/ (01.08.2013).

Joulfaian, D. (1998) "The Federal Estate and Gift Tax - Description, Profile of Taxpayers and Economic Consequences, Office of Tax Analysis, US Department of The Treasury" http://ipv6.treasury.gov/resourcecenter/tax-policy/tax-analysis/Documents/ota80.pdf, (01.01.2013).

Kalenderoğlu, M. (2006) Vergi Hukuku Türk Vergi Sistemi, 5. Baskı, Ankara, Agon Bilgi Akademisi.

Kızılot, Ş. (2013a) “Ölüm, Miras ve Vergi” Hürriyet Gazetesi, http://www.hurriyet.com.tr/yazarlar/22327823.asp, (10.03.2013).

Kızılot, Ş. (2013b) "Eş ve Çocuğa Hediye ve Banka Hesabına Ortak Etmede Son Durum Ne?” Hürriyet Gazetesi, 12 Haziran, 2013, http://www.hurriyet.com.tr/ yazarlar/23485048.asp, (22.06.2013).

Maç, M. ve Tarık, J. (2012) "Veraset, Hibe ve Ölüm” http://www.bdo.com.tr/vergi/veraset.php, (02.02.2013).

Öncel, M., Kumrulu, A. ve Çağan, N. (2003) Vergi Hukuku, 10. Baskı, Ankara, Turhan Kitabevi.

Öz, E. (2013) "Mirasçılar Dikkat! Mirasın Reddi ve Varlığın Beyan Süresi Arasındaki Çelişki Var!" http://www.muhasebetr.com/yazarlarimiz/ersan/005/, (11.03.2013).

Özbalcı, Y. (1998) Vergi Usul Kanunu Yorum ve Açıklamaları, Ankara, Feryal Matbaacılık San. ve Tic. Ltd. Şti.

Pehlivan, O. (1999) Vergi Hukuku Genel İlkeler ve Türk Vergi Sistemi, Trabzon, Eser Ofset Matbaa. 
Harvey, S.R. (2001) Public Finance 6th Edition, New Jersey, Mc Graw-Hill Irwin.

T.C. Danıştay Başkanlığı, Danıştay Bilgi Bankası, D. 7, K. No: 1999/1502, E. No: 1998/96, 15.04.1996, http://www.danistay.gov.tr/kerisim/KararNoKararC.jsp, (15.02.2013).

Tosuner, M. ve Zeynep, A. (2010) Türk Vergi Sistemi, 15. Baskı, İzmir, Kanyılmaz Matbaası.

Turhan, S. (1998) Vergi Teorisi ve Politikası, 6.Baskı, İstanbul , Filiz Kitabevi.

Türk Dil Kurumu TDK (2014) http://www.tdk.gov. tr/. (15.10.2013).

Uluatam, Ö. (2001) Kamu Maliyesi, 7. Baskı, Ankara, İmaj Yayınevi.

T.C. Maliye Bakanlığı Muhasebat Genel Müdürlüğü, Kesin Hesap ve İzleme Şubesi (2013) “2012 Yılı Merkezi Yönetim Kesin Hesabı”, http://pbk.tbmm.gov.tr/ dokumanlar/2012-kesin-hesap-tasari.pdf (29.10.2013). 
